\title{
Role of Purpurin as a Retinol-Binding Protein in Goldfish Retina during the Early Stage of Optic Nerve Regeneration: Its Priming Action on Neurite Outgrowth
}

\author{
Toru Matsukawa, ${ }^{1}$ Kayo Sugitani, ${ }^{1,2}$ Kazuhiro Mawatari, ${ }^{2}$ Yoshiki Koriyama, ${ }^{1}$ Zhongwu Liu, ${ }^{1}$ Masayuki Tanaka, ${ }^{1}$ and \\ Satoru Kato ${ }^{1}$ \\ ${ }^{1}$ Department of Molecular Neurobiology, Graduate School of Medicine, and ${ }^{2}$ School of Health Sciences, Faculty of Medicine, Kanazawa University, \\ Kanazawa, Ishikawa 920-8640, Japan
}

\begin{abstract}
Unlike mammals, the fish optic nerve can regenerate after injury. So far, many growth or trophic factors have been shown as an axon-regenerating molecule. However, it is totally unknown what substance regulates or triggers the activity of these factors on axonal elongation. Therefore, we constructed a goldfish retina cDNA library prepared from the retina treated with optic nerve transection $5 \mathrm{~d}$ previously, when it was just before regrowing optic axons after injury. A cDNA clone for goldfish purpurin for which expression was upregulated during the early stage of optic nerve regeneration was isolated from the retina cDNA library. Purpurin was discovered as a secretory retinol-binding protein in developing chicken retinas. Levels of purpurin mRNA and protein transiently increased and rapidly decreased $2-5 \mathrm{~d}$ and $10 \mathrm{~d}$ after axotomy, respectively. Purpurin mRNA was localized to the photoreceptor cells, whereas the protein was diffusely found in all of the retinal layers. A recombinant purpurin alone did not affect any change of neurite outgrowth in explant culture of the control retina, whereas a concomitant addition of the recombinant purpurin and retinol first induced a drastic enhancement of neurite outgrowth. Furthermore, the action of retinol-bound purpurin was effective only in the control (untreated) retinas but not in those primed (treated) with a previous optic nerve transection. Thus, purpurin with retinol is the first candidate molecule of priming neurite outgrowth in the early stage of optic nerve regeneration in fish.
\end{abstract}

Key words: goldfish; optic nerve regeneration; purpurin; retinol-binding protein; neurite outgrowth; retina

\section{Introduction}

Through the work of Sperry in the 1950s, it has been revealed that the CNS neurons of lower vertebrates such as fish and amphibians can regenerate after axotomy, whereas the CNS neurons of mammals become apoptotic after axotomy. Fish optic nerves are therefore one of the best-studied animal models for CNS regeneration. In goldfish, regenerating optic axons start to regrow $\sim 1$ week after injury, and almost all optic axons arrive at the tectum 3-4 weeks later (Attardi and Sperry, 1963). In contrast, rat retinal ganglion cells (RGCs) start to die 1 week after optic nerve transection (Bähr and Bonhoeffer, 1994). The recovery of some vision-related reflexes such as the startle reflex and dorsal light reflex in goldfish after optic nerve transection strongly support the regenerative property of optic nerves at a functional level (Springer and Agranoff, 1977; Kato et al., 1999). Recently, the focus on goldfish optic nerve regeneration has moved from morphological to molecular studies. Many active substances, which

\footnotetext{
Received May 11, 2004; revised July 29, 2004; accepted Aug. 5, 2004.

This work was supported in part by Core Research for Evolutional Science and Technology and research grants (12878134 to T.M.; 12680750,14034219 , 1465826, and 16027218 to S.K.; 02273 to Z.W.L.; 15922093 to Y.K.) from the Japan Ministry of Education Science, Culture and Sports and from the Honjin Foundation (to M.T.). We thank Tami Urano and Tomoko Kano for their assistance.

Correspondence should be addressed to Satoru Kato at the above address. E-mail: satoru@med.kanazawa-u.ac.jp.

D0I:10.1523/JNEUROSCI.1809-04.2004

Copyright $\odot 2004$ Society for Neuroscience $\quad 0270-6474 / 04 / 248346-08 \$ 15.00 / 0$
}

increase during optic nerve regeneration, have been reported, for example, neurotrophic factors, extracellular matrix proteins, adhesive molecules, cytoskeletal elements and enzymes such as growth associated protein-43 (Benowitz and Lewis, 1983), laminin (Hopkins et al., 1985), L1 (Ankerhold et al., 1998), $\alpha 1$ tubulin (Hieber et al., 1998), and $2^{\prime}, 3^{\prime}$-cyclic nucleotide $3^{\prime}$ phosphodiesterase (Ballestero et al., 1997).

The expression of these factors is peaked at 7-30 d after optic nerve transection, and they work as a neurite-promoting factor for axonal elongation. The results allow us to raise the following questions: what kind of molecular event does happen in the earlier stage than $7 \mathrm{~d}$ after axotomy? Is there a command substance that regulates or triggers induction of these factors in the retina? At present, we cannot answer these questions. We were particularly interested in the key molecule involved in the initiation of the regeneration process in the retina. Therefore, a cDNA library of goldfish retinas for which the optic nerve had been transectioned $5 \mathrm{~d}$ before was constructed. In the present study, differential screening of the cDNA library is performed to identify the genes of which the expression is upregulated in the early stage of regeneration. One of the cloned cDNAs encoded a goldfish homolog to chick purpurin, which is a retinol-binding protein (RBP) found in developing chicken retinas (Schubert and LaCorbiere, 1985; Schubert et al., 1986). In view of its important and specialized functions in developing chicken retina, it might be 
expected that purpurin is involved in the initiation of goldfish optic nerve regeneration. This study reports the very early and transient expression of purpurin in goldfish retina during optic nerve regeneration. It shows that purpurin expression is upregulated in photoreceptor cells but not ganglion cells. Furthermore, purpurin, when combined with retinol, induces a drastic enhancement of neurite outgrowth in the control (untreated) retina. Thus, purpurin is the first candidate molecule of priming axonal elongation in the early stage of goldfish optic nerve regeneration.

\section{Materials and Methods}

Animals and surgical procedures. Common goldfish (Carassius auratus; $6-7 \mathrm{~cm}$ in body length) were used throughout this study. Goldfish were anesthetized with ice-cold water and then the optic nerve was transectioned with scissors $1 \mathrm{~mm}$ away from the posterior of the eyeball (Devadas et al., 2000). After surgery, the goldfish were kept in a water tank and kept alive for time intervals ranging from 1 to $40 \mathrm{~d}$ at $22 \pm 1^{\circ} \mathrm{C}$.

cDNA cloning and sequence analysis. To identify the genes for which the expression was specifically upregulated during the early stage of optic nerve regeneration, a cDNA library was prepared from the goldfish retinas $5 \mathrm{~d}$ after optic nerve transection (Liu et al., 2002). Positive clones were selected by differential hybridization screening of the cDNA library using cDNA probes derived from axotomized or normal retinas as described previously (Matsukawa et al., 1996; Liu et al., 2002). The nucleotide sequences of the obtained cDNA clones on both strands were determined using an Applied Biosystems (Foster City, CA) PRISM dye terminator kit with Ampli TaqDNA polymerase (PerkinElmer Life Sciences, Foster City, CA) on a DNA sequencer (model 377; Applied Biosystems).

Northern blot hybridization of purpurin mRNA. For Northern blot analysis, total RNA was extracted from both the pretreated (with optic nerve transection) and untreated retinas using the method of Chomczynski and Sacchi (1987). Hybridization was performed three times using different samples. Three micrograms of total RNA samples was loaded on $1 \%$ agarose/formaldehyde gels and transferred overnight to nitrocellulose membrane filters (Schleisher and Schuell, Dassel, Germany). Ethidium bromide staining of the $28 \mathrm{~S}$ and $18 \mathrm{~S}$ ribosomal RNA (rRNA) was used for the loading control. Filters were then hybridized with ${ }^{32} \mathrm{P}$-labeled cDNA probes at $42^{\circ} \mathrm{C}$ overnight. After a series of washing in $2 \times$ SSC, $1 \times$ SSC, $0.5 \times$ SSC, and $0.1 \times$ SSC at $65^{\circ} \mathrm{C}$, bound radioactivity was detected using an image analyzer (BAS 1500; Fujifilm, Tokyo, Japan).

In situ hybridization. Methods for tissue fixation and cryosection were performed as described previously (Barthel and Raymond, 1990). In brief, the eyes were enucleated, dissected, and fixed in $4 \%$ paraformaldehyde solution containing $0.1 \mathrm{M}$ phosphate buffer, $\mathrm{pH} 7.4$, and $5 \%$ sucrose for $2 \mathrm{hr}$ at $4^{\circ} \mathrm{C}$. Sucrose concentrations were gradually increased from 5 to $20 \%$. The eyes were then embedded in an OCT compound (Tissue Tek; Miles, Eikhart, IN) and cryosectioned at $10 \mu \mathrm{m}$. The frozen sections were mounted onto a silane-coated glass slide and air-dried completely. In situ hybridization was performed on the goldfish retinas at various time points after optic nerve transection with digoxigenin (DIG)-labeled RNA probes using a method described previously (Komminoth, 1992). Plasmids containing $813 \mathrm{bp}$ of purpurin cDNA were linearized, and antisense and sense cRNA probes were generated with a mixture of plasmid, T3 or T7 RNA polymerase, and DIG-labeled deoxyUTP (DIG RNA Labeling Mix; Roche, Basel, Switzerland). DIG-labeled cRNA probes were hydrolyzed with $0.1 \mathrm{M} \mathrm{Na}_{2} \mathrm{CO}_{3}, \mathrm{pH} 10.2$, for $40 \mathrm{~min}$ at $60^{\circ} \mathrm{C}$. After rehybridization in a graded series of ethanol, retinal samples were incubated with 5 $\mu \mathrm{g} / \mathrm{ml}$ proteinase $\mathrm{K}$ for $5 \mathrm{~min}$ at room temperature followed by treatment with $0.1 \mathrm{M}$ triethanolamine and then with $0.1 \mathrm{M}$ triethanolamine $/ 0.25 \%$ acetic anhydride. After washing with $4 \times$ SSC, samples were incubated with $50 \%$ formamide $/ 2 \times$ SSC for $30 \mathrm{~min}$. Slides were then incubated overnight at $42^{\circ} \mathrm{C}$ in $60 \mu \mathrm{l}$ of hybridization buffer consisting of $50 \%$ formamide/10 mM Tris- $\mathrm{HCl}, \mathrm{pH} 7.5,0.6 \mathrm{~m} \mathrm{NaCl}, 1 \mathrm{~mm}$ EDTA/10\% dextran sulfate, $200 \mu \mathrm{g} / \mathrm{ml}$ tRNA, and $100 \mu \mathrm{g} / \mathrm{ml}$ heat-denatured calf thymus DNA containing $2 \mu \mathrm{g}$ of cRNA probes. After washing with $50 \%$ formamide $/ 2 \times$ SSC, the samples were treated with RNase A $(20 \mu \mathrm{g} / \mathrm{ml})$ for $30 \mathrm{~min}$ at $37^{\circ} \mathrm{C}$ and then blocked with a $1.5 \%$ blocking solution (Roche). To detect the signals, samples were incubated with an anti-DIG antibody conjugated to alkaline phosphatase overnight at $4^{\circ} \mathrm{C}$ and visualized with 4-nitroblue tetrazolium chloride/5-bromo-4-chloro-3-indolyl phosphate (Roche). Sections were mounted in 90\% glycerol and photographed using a light microscope (Nikon, Tokyo, Japan) and digital camera.

Western blot hybridization. Anti-peptide antiserum against purpurin was prepared from a synthetic peptide of purpurin (see Fig. 1, dotted line) by Sigma-Aldrich Japan K. K. (Tokyo, Japan). During Western blot analysis, the retinas from two to three eyes were isolated and suspended in $0.4 \mathrm{ml}$ of mixture consisting of $0.1 \times$ PBS, $0.1 \%$ SDS, $1 \mathrm{~mm}$ PMSF solution. After sonication with a supersound sonicator (Astrason, Farmingdale, NY) at $4^{\circ} \mathrm{C}$, the supernatants were loaded on SDS polyacrylamide (15\%) gel and analyzed by Western blot analysis as described previously (Li et al., 1998). Protein was measured using the method of Lowry et al. (1951) with BSA as the standard. After transferring the samples to membrane filters, the protein bands were reacted with antipurpurin peptide antibody (dilution, 1:300). After washing, the membrane filters were reacted with peroxidase-conjugated anti-rabbit IgG antibody (dilution, 1:500; MBL, Nagoya, Japan). Aliquots were subjected to SDS-PAGE because the same amount of protein in each lane, which was confirmed by the same amount of histone $\mathrm{H} 4$ protein, stained with Coomasie Brilliant Blue R-250 (CBB).

Immunohistochemistry. Methods for tissue fixation and cryosectioning were the same as those described in the in situ hybridization section. Samples were autoclaved at $121^{\circ} \mathrm{C}$ for $15 \mathrm{~min}$ in $10 \mathrm{~mm}$ citrate buffer. After washing and blocking, sections were incubated with the antipeptide antibody to purpurin (dilution, 1:300) overnight at $4^{\circ} \mathrm{C}$, followed by $1 \mathrm{hr}$ incubation with a biotinylated secondary anti-rabbit IgG (dilution, 1:500; Santa Cruz Biotechnology, Santa Cruz, CA) at room temperature. Bound antibodies were developed with HRP-conjugated streptavidin and 3-amino-9-ethylcarbazole (Dako Cytomation, Glostrup, Denmark).

Purification of recombinant purpurin. Purpurin cDNA fragments (corresponding to 22-196 amino acid residues) were amplified by PCR and inserted into a pET-Thioredoxin (Trx) fusion system 32 plasmid at BamHI-EcoRI site (Novagen, Darmstadt, Germany). Trx-purpurin fusion protein was purified according to the instructions of the manufacturer. Briefly, after sonication of Escherichia coli, the homogenates were centrifuged, and precipitates were collected. The protein precipitates were dissolved in $6 \mathrm{~m}$ urea and exposed to step dialysis with $4,2,1$, and 0 $\mathrm{m}$ urea in $10 \mathrm{~mm}$ Tris- $\mathrm{HCl}, \mathrm{pH} 7.5,10 \mathrm{~mm} \mathrm{NaCl}$. After centrifugation, the supernatants obtained were applied to Ni column chromatography. The Trx-purpurin fusion protein (recognized as a $42 \mathrm{kDa}$ protein) was eluted with $1 \mathrm{~m}$ imidazole, $0.5 \mathrm{~m} \mathrm{NaCl}, 80 \mathrm{~mm}$ Tris-HCl, $\mathrm{pH}$ 7.9. After dialysis, the fusion protein was digested with enterokinase to release the Trx portion followed by the enterokinase, and then the released Trx fragments were removed by affinity chromatography. Purified recombinant purpurin was obtained, and the purity was checked by SDS-PAGE. One main purpurin band (recognized as a $24 \mathrm{kDa}$ protein) and several faint bands were observed (purity, >98\%).

Retinal explant culture. The retinal explant culture was performed as described previously (Johns et al., 1978). Briefly, pretreated and untreated adult goldfish retinas were isolated under sterile conditions and sectioned into $0.5 \mathrm{~mm}$ square pieces with scissors. Retinal explants were collected and cultured on a polyornithine-coated culture dish $(35 \mathrm{~mm})$ in HEPES L-15, pH 7.4, medium with $10 \%$ fetal calf serum at room temperature. The effects of recombinant purpurin, retinol (all-trans; Sigma), retinoic acid (all-trans; Sigma), and disulphiram (Wako) were tested by adding each to the culture medium. The anti-purpurin antibody was purified by affinity chromatography on protein G-Sepharose (Amersham Biosciences, Arlington Heights, IL). The anti-purpurin (IgG; $5-10 \mu \mathrm{g} / \mathrm{ml}$ ) was also added to the medium. Retinoic acid added was removed from the medium after an initial $2 \mathrm{~d}$ of culture. Neurite outgrowth from the retinal explants was assayed by counting the number of explants bearing neurite outgrowths in $35 \mathrm{~mm}$ culture dishes (40-50 explants per dish). The positive neurites were defined by their length and density (Landreth and Agranoff, 1976). In this study, the explants having neurites $>150 \mu \mathrm{m}$ in length and more than five in number were counted. Four to five independent experiments were conducted. 
Statistics. The neurite outgrowths from the retinal explants under various culture conditions were expressed as a percentage of the number of neurite-bearing explants per $40-50$ explants in a $35 \mathrm{~mm}$ dish. Data were expressed as the mean $\pm \mathrm{SD}$, and statistical differences were evaluated using Scheffe's one-way ANOVA.

\section{Results}

Identification of purpurin cDNA

To identify the molecules involved in the early stage of optic nerve regeneration, differential screening of a cDNA library prepared from goldfish retinas $5 \mathrm{~d}$ after optic nerve transection was performed. Several clones became strongly hybridized with the cDNA probe derived from the axotomized retinas, but the hybridization with the cDNA probe from the normal retinas was very weak (Liu et al., 2002). The nucleotide sequence of one of the clones was determined. The cDNA was $813 \mathrm{bp}$ in length and contained a 588 bp open reading frame (DNA Data Bank of Japan, Mishima, Japan; GenBank accession number AB111522). The deduced amino acid sequence, which had a calculated molecular weight of $22.1 \mathrm{kDa}$ (196 amino acids residues), is shown in Figure 1. A predicted signal peptide for secretion existed in the $\mathrm{N}$-terminal region (Fig. 1, underlined). This protein was a member of the RBP family and had a particularly high homology to chicken purpurin (80\% homology) (Fig. 1, short vertical bars) and human serum RBP (50\% homology). Purpurin is a retinaspecific RBP and has only been sequenced in chicken retina (Berman et al., 1987). Thus, because of its high sequence homology to chicken purpurin, it was concluded that this cDNA clone is a goldfish purpurin homolog.

\section{Purpurin mRNA after optic nerve transection}

Total RNA was isolated from retinas at various time points after optic nerve transection, and changes in the amount of purpurin mRNA were determined by Northern blot hybridization using a cDNA probe encoding purpurin. One major band, shorter than $18 \mathrm{~S}$ rRNA in length and judged as purpurin mRNA from the length of the cDNA, was observed in the autoradiogram (Fig. 2A). The purpurin band (Fig. $2 A$ ) in each lane was normalized with the intensities of the $18 \mathrm{~S}$ and $28 \mathrm{~S}$ rRNAs in a gel stained with ethidium bromide. The purpurin mRNA increased approximately twofold 2-5 d after optic nerve transection and then rapidly declined to the control level by $10 \mathrm{~d}$ after axotomy. In contrast, the amount of tubulin mRNA did not change significantly during this period. The rapid and transient increase in purpurin mRNA after optic nerve transection is quantitatively plotted in Figure $2 B$. Purpurin mRNA was specifically expressed in the retina but not in the tectum (Fig. 2C), cerebellum, or liver (data not shown).

56 amino acid residue.
1

55

MEYYKFALLVVFLSYIERCWSSSCVVDSFTVKDDFDPKRYÄGKWYAQQKKDPEGL

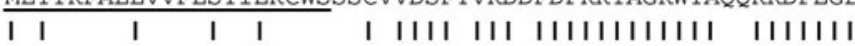
MKYAQYVFLASIFSAVEYSLAQTCAVDSFSVKDNFDPKRYAGKWYALAKKDPEGL 125 FLQDNISAEYTIDDDGTMTASSKGRVTLFGFWVVCADMAAQYSVPDPSTPGKMFMNYQGLASYLSSGGDN |IIIIIII IIIIIIIIIIIIIII IIIIII IIIII II IIIIIIIIIII $126 \quad 196$ YWVIDTDYDNYAITYACRTLKDDGTCEDGYALVFSRNPRGLPPAIQRLVRQKQDEICMAGQFQPVLQSGAC IIIIIIIIIIIIIII I I II IIIIIIIIIIIIIII III IIIIIIII

Figure 1. Deduced amino acid sequence of the cDNA clone. Top trace, Goldfish cDNA clone. Bottom trace, Chicken purpurin (Berman et al., 1987). Underlined area, Predicted signal peptide sequence in the N terminus. Dotted line, Site of synthetic peptide

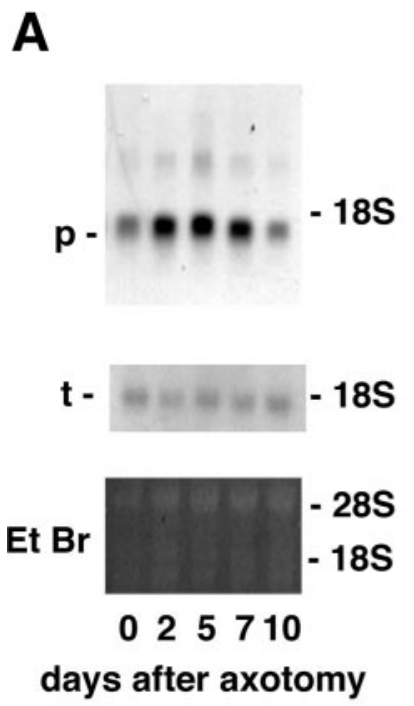

B

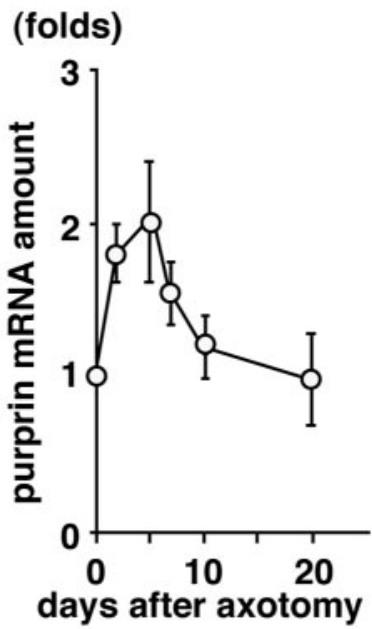

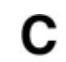

retina tectum

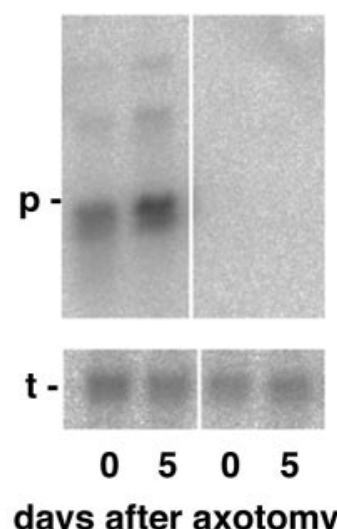

\section{p: purpurin t: tubulin}

Figure 2. Upregulation of purpurin mRNA after optic nerve transection. A, Northern blot hybridization of purpurin mRNA. Top panel, Autoradiograms of purpurin mRNA at various times (days) after optic nerve transection. Middle panel, Autoradiograms of $\alpha$-tubulin mRNA. Northern blot hybridization was conducted using cDNA probes of purpurin and $\alpha$-tubulin. Bottom panel, The relationship between purpurin mRNA and the time after optic nerve transection is plotted. The values are presented as the mean \pm SD of three independent experiments. C, Retina-specific expression of purpurin mRNA. Total RNAs from the retina (left) and tectum (right) at 0 and $5 \mathrm{~d}$ after optic nerve transection were loaded onto agarose/formamide gel.

Next, the localization of purpurin mRNA in the retina was studied using an in situ hybridization method. As shown in Figure $3 A$, the signal of purpurin mRNA detected with an antisense cRNA probe was faintly detected only in the outer nuclear layer (ONL) of the control retina. The intensity of the mRNA signal dramatically increased, peaking $5 \mathrm{~d}$ after optic nerve transection (Fig. $3 B$ ), whereas no signal was observed in the same retina with a sense probe (Fig. $3 C$ ). The signal of purpurin mRNA in the ONL detected with an antisense probe rapidly declined $10 \mathrm{~d}$ after optic nerve transection (Fig. 3D).

\section{Purpurin protein after optic nerve transection}

To determine purpurin protein levels in the retina after optic nerve transection, an anti-peptide antibody against purpurin was constructed. The synthetic peptide used for making the antiserum is indicated by a dotted line in Figure 1. Using Western blot 


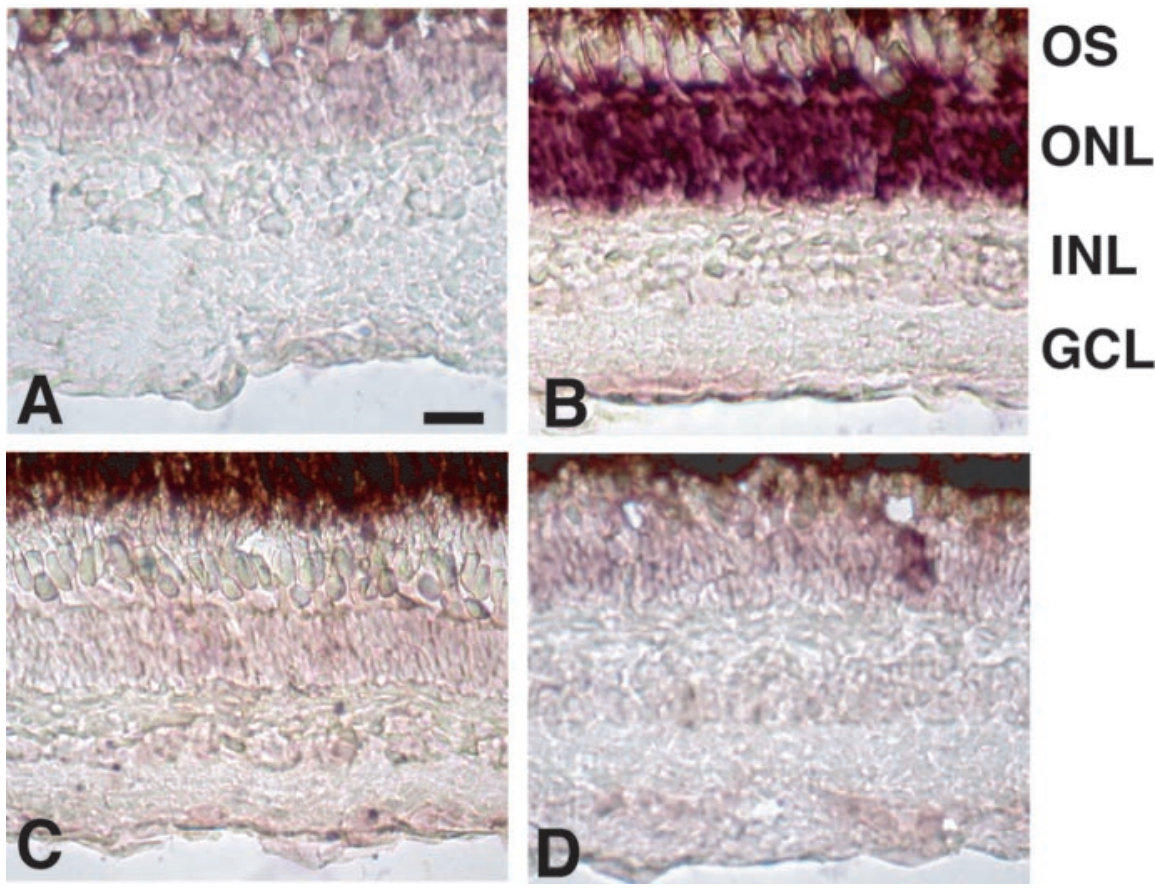

Figure 3. In situ hybridization of purpurin mRNA. $A, B$, The purpurin mRNA signal detected with an antisense probe was dramatically enhanced in the photoreceptor cells $5 \mathrm{~d}(B)$ after optic nerve transection compared with the control $(A)$. C, No positive signal could be seen $5 \mathrm{~d}$ after optic nerve transection with a sense riboprobe. $D$, The signal rapidly declined by $10 \mathrm{~d}$ after optic nerve transection. GCL, Ganglion cell layer; INL, inner nuclear layer; OS, outer segment. Scale bar, $20 \mu \mathrm{m}$.

A

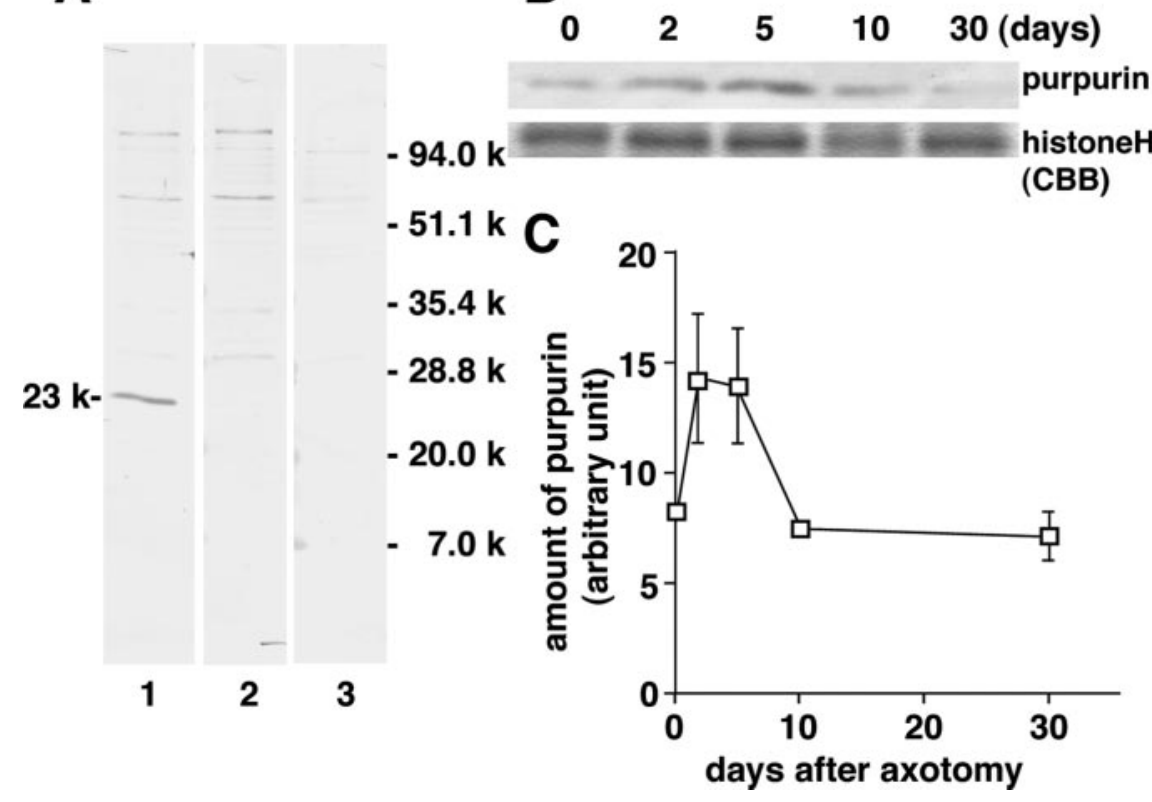

Figure 4. Increase in purpurin protein after optic nerve transection. $A$, Western blot analysis of purpurin. After electrophoresis and the transfer of proteins, membrane filters were incubated with anti-purpurin antiserum (lane 1), antiserum pretreated with excess amounts of antigen peptide (lane 2), and preimmune serum (lane 3). A specific purpurin band is shown at $23 \mathrm{kDa} . B$, Increase in purpurin protein after optic nerve transection. Retinal samples were prepared various days after optic nerve transection and loaded onto SDS gel. Top trace, Purpurin band obtained with Western blot analysis. Bottom trace, Histone H4 band stained with CBB for normalization. C, The relationship between purpurin and days after axotomy. The values represent the mean $\pm S D$ of purpurin band intensity (an arbitrary unit) in three independent experiments.

analysis, a major protein band was observed in the control retina at $23 \mathrm{kDa}$ with purpurin antiserum treatment (Fig. $4 \mathrm{~A}$, lane 1). Only this band disappeared with a pretreatment absorption of excess amounts of antigen peptide (lane 2). The other faint bands in the control retina did not disappear with this treatment (lane 2). Therefore, it was concluded that this 23 $\mathrm{kDa}$ protein band is purpurin, which from the deduced amino acid sequence is expected to have a similar molecular weight. The other faint bands in the control retina were recognized as nonspecific bands (Fig. $4 A$, compare lanes 1 and 2). Treatment with preimmune serum did not produce a $23 \mathrm{kDa}$ band (lane 3). The intensity of the purpurin band increased approximately twofold 2-5 d after optic nerve transection and then rapidly decreased to the control level by $10 \mathrm{~d}$ after axotomy (Fig. $4 \mathrm{~B}$ ). The protein band shown as histone $\mathrm{H} 4$ protein did not change in level during this period.

Next, the immunohistochemical localization of the secretory purpurin protein in the retina was investigated with the antipeptide antiserum. In the control retina, the immunoreactivity of purpurin was faintly detected in the outer and inner nuclear layers (Fig. 5A). At $5 \mathrm{~d}$ after optic nerve transection, the red immunoreactive signals increased diffusely in all of the nuclear layers, particularly in the outer parts of the photoreceptor, inner parts of the inner nuclear layer, and ganglion cell layers (Fig. 5B). This rapid and diffuse increase in the immunoreactivity almost disappeared by $20 \mathrm{~d}$ after axotomy (Fig. $5 C$ ). No positive staining could be seen in the retina with preimmune serum (Fig. 5D).

Purpurin with retinol promotes neurite outgrowth in retinal explant cultures

To examine the functional role of purpurin in the early stage (2-5 d after optic nerve transection) of optic nerve regeneration, we investigated whether or not neurite outgrowths from retinal explants of adult goldfish were affected by purpurin. The neurite outgrowth was scored by measuring the explants with long and dense neurites. A weak and spontaneous neurite outgrowth was evoked by culturing the control retinas (no treatment) (Fig. 6A). Only a few short and thin neurites could be seen after $5 \mathrm{~d}$ of culture. In contrast, extensive and spontaneous neurite outgrowths were evoked by culturing the retina that had undergone an optic nerve transection 5-7 d previously (Fig. 6B). A large number of long and thick neurites could be seen until $5 \mathrm{~d}$ of culture. This is called "priming" action on neurite outgrowth in the retina with pretreatment of optic nerve transection (Landreth and Agranoff, 1976).

The contribution of purpurin to neurite extension was studied using a recombinant protein of purpurin or antipurpurin antiserum. The recombinant purpurin ( $24 \mathrm{kDa}$ protein) was ob- 
tained from E. coli transfected with a plasmid vector inserted with an encoding purpurin cDNA fragment. The recombinant purpurin $(1 \mu \mathrm{g} / \mathrm{ml})$ alone did not cause any change in neurite outgrowths in the control retina during $5 \mathrm{~d}$ of culture (Fig. $6 C)$. Because purpurin is a retinol-binding protein, the effect of retinol on neurite outgrowth was tested. Similarly, retinol (1 $\mu \mathrm{M})$ alone did not affect any change in neurite outgrowth (Fig. 6D). However, a concomitant addition of purpurin $(1 \mu \mathrm{g} /$ $\mathrm{ml})$ with retinol $(1 \mu \mathrm{M})$ to the medium induced a drastic enhancement of neurite outgrowth in the control retina (Fig. $6 E$ ). A large number of long and thin neurites could be seen during $5 \mathrm{~d}$ of culture. The neurite outgrowths evoked by purpurin with retinol in the control retina resembled the neurite outgrowth in the primed retina, which had undergone optic nerve transection 5-7 d previously, except for its thinner neurites (Fig. 6, compare $B$ and $E$ ). The effect of purpurin was dose dependent (10 ng to $1 \mu \mathrm{g} / \mathrm{ml}$ ), and heat-inactivated purpurin with retinol was not effective (data not shown). The drastic enhancement of neurite outgrowth with purpurin and retinol was limited to the control retinas (Fig. 6E) and was not seen in the primed retina, which had undergone optic nerve transections 5-7 d previously. The long and thick outgrowing neurites were not affected by purpurin with retinol (data not shown).

Purpurin with retinol, but not purpurin alone, dramatically enhanced neurite outgrowths in the control retina. To further examine the role of retinol, the effect of retinoic acid, a retinoid, on neurite outgrowth was tested. Retinoic acid ( $1 \mu \mathrm{M})$ induced comparable neurite outgrowths in the control retina to those induced by purpurin plus retinol during $5 \mathrm{~d}$ of culture (Fig. $6 F$ ), compared with the control culture (Fig. 6A). A large number of long and thin neurites could be seen during the $5 \mathrm{~d}$ of culture. In the presence of disulphiram $(10 \mu \mathrm{M})$, a specific inhibitor of the retinoic acid synthesizing enzyme (McCaffery et al., 1992), the neurite promoting effect of purpurin with retinol was completely blocked (Fig. 6G). A few short and thin neurites could be seen after $5 \mathrm{~d}$ of culture as in the control culture. The disulphiram (10 $\mu \mathrm{M})$ alone did not affect any change of neurite outgrowth in the control retina (Fig. $6 H$ ).

Figure 7 quantitatively summarizes the time course of neurite outgrowth over $5 \mathrm{~d}$ under various culture conditions. Figure $7 \mathrm{~A}$ shows the time course of spontaneous neurite outgrowths in the control (no treatment) retinas (Fig. 6A). Anti-purpurin antiserum clearly inhibited $90 \%$ of the spontaneous neurite outgrowths in the control retinas. Preimmune serum was ineffective on the neurite outgrowth. Figure $7 B$ shows the time course of spontaneous neurite outgrowths in the primed retina, which underwent optic nerve transection 5-7 d previously (Fig. 6B). Anti-purpurin antiserum inhibited only $45 \%$ of the neurite outgrowths in the primed retina. Preimmune serum did not affect any change of neurite outgrowth. Figure $7 C$ shows the time course of the neurite outgrowths in the control retinas with purpurin alone or purpurin with retinol (Fig. 6C,E). Figure $7 D$
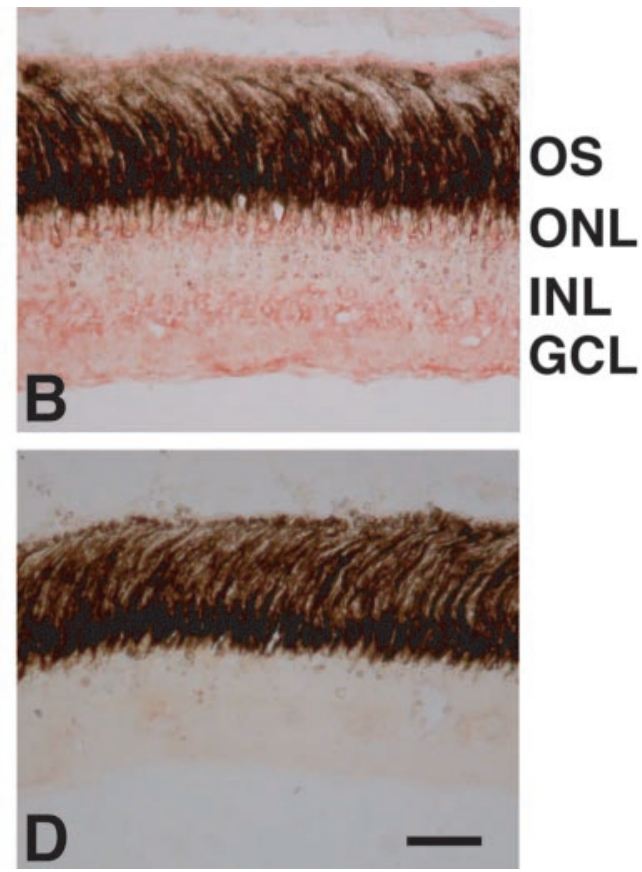

Figure 5. Immunohistochemical study of purpurin in the retina. $A-D$, Retinal sections from various days after optic nerve tivity could be seen in the retina $5 \mathrm{~d}$ after optic nerve transection with preimmune serum $(D)$. INL, Inner nuclear layer; $\mathrm{GCL}$, ganglion cell layer; $0 S$, outer segment. Scale bar, $20 \mu \mathrm{m}$.

shows the time course of neurite outgrowths in the control retinas with retinoic acid, purpurin with retinol plus disulphiram, and retinoic acid plus disulphiram (Fig. 6F, $G$ ). Disulphiram totally inhibited the neurite outgrowths induced by purpurin with retinal but not by retinoic acid. Figure $7 E$ quantitatively compares the number of neurite outgrowing explants in the control retinas with the purpurin and retinoids after $5 \mathrm{~d}$ of culture. Purpurin with retinol and retinoic acid significantly induced a 1.7- to 1.8 -fold increase in neurite outgrowths compared with the control culture $\left({ }^{*} p<0.01\right.$ vs control). The enhancement of neurite outgrowths evoked by purpurin with retinol was completely blocked by disulphiram $\left({ }^{* *} p<0.01\right.$ vs purpurin with retinol).

\section{Discussion}

Very early and transient increase in purpurin mRNA in the photoreceptor cells during optic nerve regeneration

To identify the molecules involved in the early stage of optic nerve regeneration, a cDNA cloning technique was performed with differential screening of a cDNA library prepared from goldfish retinas $5 \mathrm{~d}$ after optic nerve transection. Positive clones for which the expression was upregulated in the early stage of optic nerve regeneration were selected with cDNA probes derived from normal and axotomized retinas. One clone was hybridized, sequenced, and identified as a goldfish homolog to chick purpurin, which is a $20 \mathrm{kDa}$ secretory protein (Schubert and LaCorbiere, 1985). Purpurin was originally discovered as a chick neural retina adhesive and cell survival molecule and a secretory retinolbinding protein (Schubert et al., 1986). The sequence, cellular localization, and expression of chick retina purpurin have also been analyzed (Berman et al., 1987). Chick purpurin mRNA was found in both embryonic and adult retinas but not in the brain or liver. This mRNA was expressed only in the photoreceptor cells of chick retinas (Berman et al., 1987). The predicted purpurin se- 

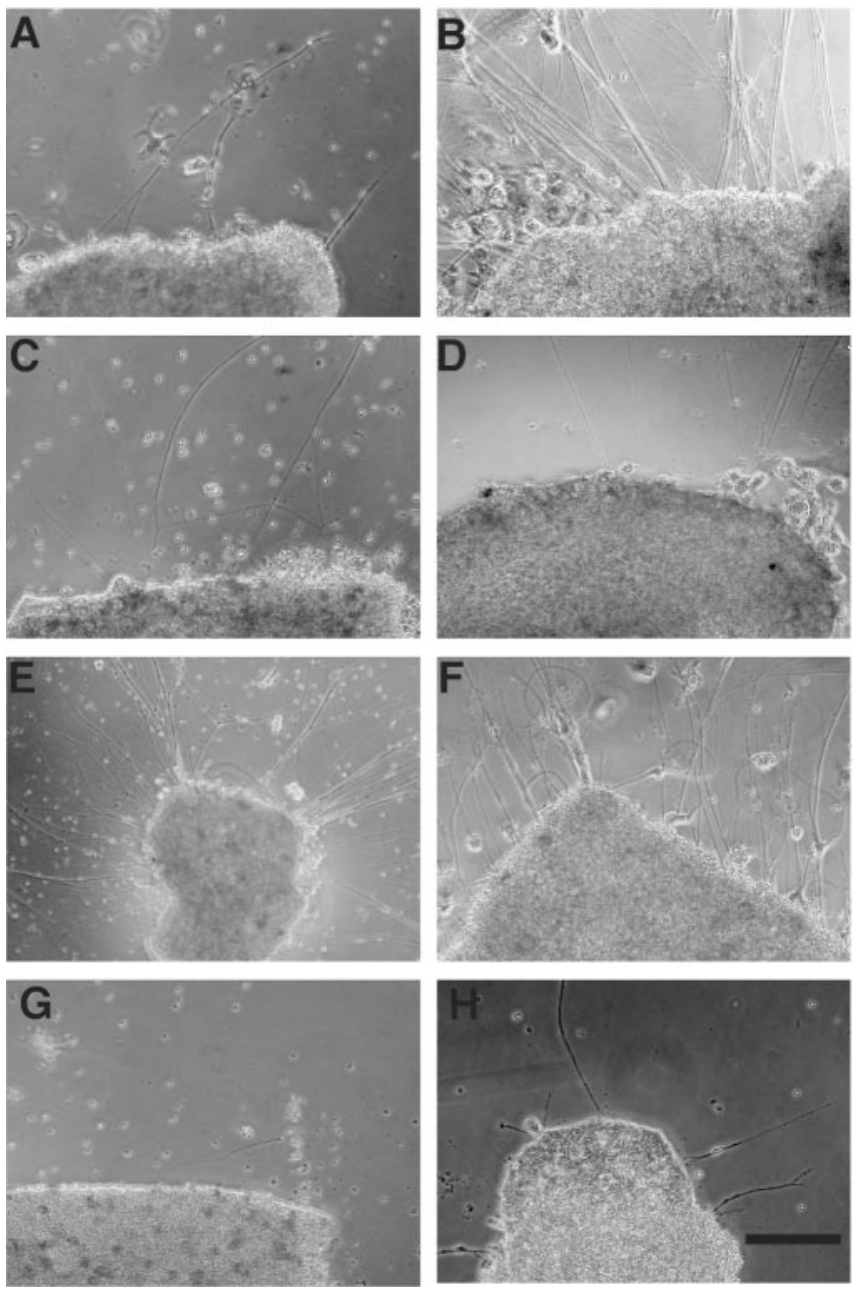

Figure 6. Neurite outgrowth in adult goldfish retinas. Retinal explants were cultured for $5 \mathrm{~d}$. $A$, No addition, control retina. $B$, No addition, primed retina (underwent optic nerve transection 5-7 d previously). C, Purpurin (1 $\mu \mathrm{g} / \mathrm{ml})$ added to the control retina. D, Retinol $(1 \mu \mathrm{M})$ added to the control retina. $E$, Purpurin $(1 \mu \mathrm{g} / \mathrm{ml})$ with retinol $(1 \mu \mathrm{m})$ added to the control retina. $F$, Retinoic acid $(1 \mu \mathrm{M})$ added to the control retina. G, Purpurin with retinol and disulphiram (10 $\mu \mathrm{m})$ added to the control retina. $H$, Disulphiram $(10 \mu \mathrm{M})$ added to the control retina. Scale bar, $200 \mu \mathrm{m}$.

quence contained 196 amino acid residues, which had an $~ 50 \%$ sequence homology with human serum retinol-binding protein (Berman et al., 1987). The cDNA clone in the present study had a high homology to chick purpurin $(80 \%)$ and human serum retinol-binding protein $(50 \%)$ and showed a retina-specific expression in Northern blot analysis (Figs. 1,2). The size identity of mRNA or protein to chick purpurin and the existence of signal peptides for secretion or $\beta$-barrel structures that characterize retinol-binding proteins in the sequence data further confirmed the similarity of both molecules to purpurin (Berman et al., 1987; Noy, 2000). Therefore, purpurin was cloned for the first time as an active molecule upregulated in goldfish retina after optic nerve injury.

In the present study, Northern blot analysis revealed that purpurin mRNA rapidly increased twofold in goldfish retina by $2 \mathrm{~d}$ after optic nerve transection. This increase lasted for 2-3 d and then rapidly decreased by $10 \mathrm{~d}$ after axotomy. In situ hybridization for purpurin mRNA further demonstrated that this rapid and transient increase occurs only in the photoreceptor cells 2-5 $\mathrm{d}$ after optic nerve lesion. Thus, purpurin is a very unusual mol-
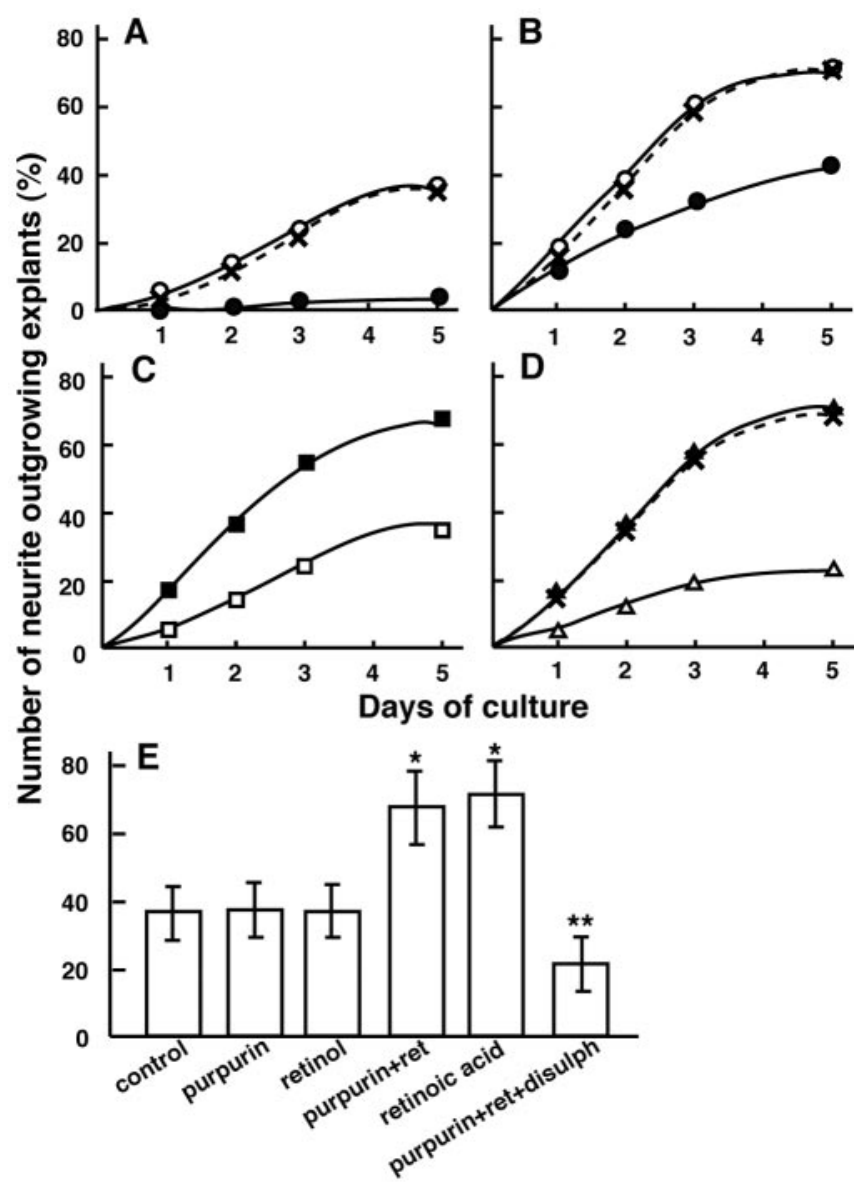

Figure 7. Time course of neurite outgrowths in the retinal explant culture under various conditions. $A$, No addition, control retina $(\bigcirc)$; addition of anti purpurin lgG $(5-10 \mu \mathrm{g}$; $)$; addition of preimmune $\lg G(5-10 \mu \mathrm{g} ; \times)$. B, No addition, primed retina (underwent optic nerve transection 5-7 d previously; $\bigcirc)$; addition of anti purpurin $\lg \mathrm{G}(5-10 \mu \mathrm{g}$; $)$; addition of preimmune lgG $(5-10 \mu \mathrm{g} ; \times)$. C, Addition of purpurin $(1 \mu \mathrm{g} / \mathrm{ml} ; \square)$ or purpurin $(1 \mu \mathrm{g} / \mathrm{ml})$ with retinol (1 $\mu \mathrm{m} ; \mathbf{\square})$. D, Addition of retinoic acid $(1 \mu \mathrm{m} ; \mathbf{\Delta})$; purpurin with retinol and disulphiram $(10 \mu \mathrm{m} ; \triangle)$; retinoic acid $(1 \mu \mathrm{m})$ with disulphiram $(10 \mu \mathrm{m} ; \times)$. E, Neurite outgrowth with the addition of purpurin and retinoids to the control retina during $5 \mathrm{~d}$ of culture. Note a drastic enhancement of neurite outgrowth was seen with the addition of purpurin with retinol or retinoic acid. Note a complete blockage of the neurite-promoting effect of purpurin with retinol by addition of disulphiram $\left({ }^{*} p<0.01\right.$ vs control and ${ }^{* *} p<0.01$ vs purpurin with retinol).

ecule with regards to its induction period and cellular localization during fish optic nerve regeneration.

So far, many factors/substances that are involved in goldfish optic nerve regeneration have been found. All are induced (activated) 5-20 d after optic nerve transection and usually act for a long time (10-30 d). For example, a Na,K-ATPase $\alpha 3$ subunit cDNA was cloned into goldfish retina during optic nerve regeneration (Liu et al., 2002). The mRNA for Na,K-ATPase $\alpha 3$ subunit increased in the ganglion cells and nerve fiber layers 5-20 d after optic nerve transection. An in vitro culture system clearly showed that the $\mathrm{Na}, \mathrm{K}$-ATPase $\alpha 3$ subunit played a positive role in the neurite outgrowths of regenerating optic axons. Furthermore, a wheat germ agglutinin-horseradish peroxidase neurotracing study revealed that the regenerating optic axons of goldfish start to regrow after 7-10 d and completely arrive at the optic tectum by $18-30 \mathrm{~d}$ after optic nerve transection (Kato et al., 1999). Therefore, the induction period of $2-5 \mathrm{~d}$ after axotomy for purpurin was a little different with regards to the early initiation and transient duration in the expression of these regeneration- 
related substances and occurred just before the regrowth of the optic axons.

All of the regeneration-related substances mentioned above were without exception limited to the ganglion cells, nerve fiber layer, and surrounding glia in the optic nerves. The optic nerve is composed of both centripetal (afferent) and centrifugal (efferent) fibers. Thus, certain sections of the optic nerves remove the influence from the CNS. It has been reported that transections of the optic nerve affect photoreceptor plasticity or rhodopsin content in the rods of rat (Schremser and Williams, 1992). In goldfish retina, lesions of the optic nerve enhance the proliferation of rod precursors in the outer nuclear layer (Owusu-Yaw et al., 1992). Such a mitogenic factor, which affects photoreceptors, might promote the transcriptional activation of the purpurin gene via interplexiform cells in the inner nuclear layer through centrifugal fibers (Stell et al., 1984).

\section{Functional role of purpurin as a retinol bound form in the early stage of optic nerve regeneration}

A concomitant addition of purpurin with retinol first induced a dramatic enhancement of neurite outgrowth in the control retinas. This enhanced neurite outgrowth was not detected in the retinas primed with optic nerve transection 5-7 d previously. The antiserum against purpurin specifically inhibited the neurite outgrowth in the control retina $(>90 \%)$ but not in the primed retina $(<45 \%)$, respectively (Fig. $7 A, B)$. The partial block of neurite outgrowth in the primed retina by anti-purpurin antiserum may be attributable to still remaining activity of purpurin secretion in the primed retina. These results support the fact that purpurin works in the early stage of optic nerve regeneration (2-5 d after optic nerve transection). Because purpurin is a secretory protein, the stimulatory effect of recombinant purpurin with retinol and the inhibitory effect of neutralizing antiserum against purpurin on neurite outgrowth are reasonable. The secretion of purpurin was confirmed by the existence of signal sequences and the detection of its protein in a retinal culture medium using Western blot analysis (T. Matsukawa, unpublished data). Furthermore, an immunohistochemical study of goldfish retina revealed that diffuse and intense immunoreactivity in all nuclear layers containing ganglion cell layers could be seen $2-5 \mathrm{~d}$ after optic nerve transection (Fig. 5). These data strongly suggest that purpurin is secreted not only as an adhesive and cell survival factor but also as a neurite-promoting factor particularly with retinol in matured ganglion cells after optic nerve injury. Therefore, a new working hypothesis of purpurin as a retinol transporter can be proposed.

Interphotoreceptor RBP (IRBP) and purpurin are retinoidbinding proteins found in the retina (Flower, 1994; GonzalezFernandez, 2002). IRBP transports retinal to photoreceptor cells for the visual cycle. Retinol-binding proteins, including purpurin, are lipocalin proteins, which are a family of extracellular soluble proteins that transport small hydrophobic molecules. They have a conserved structure, which includes a calyx formed by a $\beta$-barrel with a hydrophobic ligand pocket (Flower et al., 2000). This protein family is further characterized by several common molecular recognition properties, namely the ability to bind a range of small hydrophobic molecules and the ability to bind to specific surface receptors. The drastic enhancement of neurite outgrowths evoked by retinol-bound purpurin might be explained by binding to the cell surface receptors leading to neurite elongation. Although the correct signal pathways that result in neurite elongation are not clear, there are two possibilities: one is that retinol-bound purpurin is taken up into the cells and thereafter metabolized into retinoic acid by retinaldehyde dehy- drogenase (RALDH). Retinoic acid induced a comparable neurite outgrowth in the control retinas as was induced by purpurin with retinol (Fig. 6 E), whereas disulphiram, a specific inhibitor of RALDH-2, completely blocked the neurite outgrowths evoked by purpurin with retinol (Fig. 6G). These results strongly indicate that retinoic acid participates in retinol-bound purpurininduced neurite outgrowths. The importance of retinoic acid and RALDH-2 is well known in developing retina (Mey et al., 1997; Stull and Wikler, 2000) and adult mouse dorsal root ganglia (Corcoran and Maden, 1999). Recently, the activation of retinoic acid signaling after sciatic nerve injury was reported in rats (Zhelyaznik et al., 2003).

Another possible explanation for neurite elongation is that retinol-bound purpurin binds to its receptors and thereby links to a machinery involving neurite outgrowth. In grasshopper embryonic neurons, Lazarillo, a novel lipocalin, is involved in axonal pathfinding (Ganfornina et al., 1995). This protein anchors to the plasma membranes and restricts to a subset of developing neurons. The hypothesis that retinol-bound purpurin has a priming action similar to the effect of lipocalin on neurite elongation in the early stage of adult goldfish optic nerve regeneration is possible when considering a common signal pathway for retinoids in the early stage of CNS development. Additional explorations of cellular retinoid binding proteins or retinoid metabolism in goldfish retina are needed in the future. Finally, we discuss the relevance of purpurin to axonal regeneration in mammals. Although we have tried to screen a rat homologous to purpurin cDNA, we cannot succeed it yet. Another retinol-binding protein might work in the other nervous system (Zhelyaznik et al., 2003).

\section{References}

Ankerhold R, Leppert CA, Bastmeyer M, Stuermer CA (1998) E587 antigen is upregulated by goldfish oligodendrocytes after optic nerve lesion and supports retinal axon regeneration. Glia 23:257-270.

Attardi DG, Sperry RW (1963) Preferential selection of central pathways by regenerating optic fibers. Exp Neurol 7:46-64.

Bähr M, Bonhoeffer F (1994) Perspectives on axonal regeneration in the mammalian CNS. Trends Neurosci 17:473-479.

Ballestero RP, Wilmot GR, Agranoff BW, Uhler MD (1997) gRICH68 and gRICH70 are 2' $3^{\prime}$-cyclic nucleotide $3^{\prime}$-phosphodiesterases induced during goldfish optic nerve regeneration. J Biol Chem 272:11479-11486.

Barthel LK, Raymond PA (1990) Improved method for obtaining 3-microns cryosections for immunohistochemistry. J Histochem Cytochem 38:1383-1388.

Benowitz LI, Lewis ER (1983) Increased transport of 44,000- to 49,000dalton acidic proteins during regeneration of the goldfish optic nerve: a two-dimensional gel analysis. J Neurosci 3:2153-2163.

Berman P, Gray P, Chen E, Keyser K, Ehrlich D, Karten H, LaCorbiere M, Esch F, Schubert D (1987) Sequence analysis, cellular localization, and expression of a neuroretina adhesion and cell survival molecule. Cell 51:135-142.

Chomczynski P, Sacchi N (1987) Single-step method of RNA isolation by acid guanidinium thiocyanate-phenol-chloroform extraction. Anal Biochem 162:156-159.

Corcoran J, Maden M (1999) Nerve growth factor acts via retinoic acid synthesis to stimulate neurite outgrowth. Nat Neurosci 2:307-308.

Devadas M, Sugawara K, Shimada Y, Sugitani K, Liu ZW, Matsukawa T, Kato S (2000) Slow recovery of goldfish retinal ganglion cells' soma size during regeneration. Neurosci Res 37:289-297.

Flower DR (1994) The lipocalin protein family: a role in cell regulation. FEBS Lett 31:7-11.

Flower DR, North AC, Sansom CE (2000) The lipocalin protein family: structural and sequence overview. Biochim Biophys Acta 1482:9-24.

Ganfornina MD, Sanchez D, Bastiani MJ (1995) Lazarillo, a new GPI-linked surface lipocalin, is restricted to a subset of neurons in the grasshopper embryo. Development 121:123-134.

Gonzalez-Fernandez F (2002) Evolution of the visual cycle: the role of retinoid-binding proteins. J Endocrinol 175:75-88. 
Hieber V, Dai X, Foreman M, Goldman D (1998) Induction of alpha1tubulin gene expression during development and regeneration of the fish central nervous system. J Neurobiol 37:429-440.

Hopkins JM, Ford-Holevinski TS, McCoy JP, Agranoff BW (1985) Laminin and optic nerve regeneration in the goldfish. J Neurosci 5:3030-3038.

Johns PR, Heacock AM, Agranoff BW (1978) Neurites in explant cultures of adult goldfish retina derived from ganglion cells. Brain Res 142:531-537.

Kato S, Devadas M, Okada K, Shimada Y, Ohkawa M, Muramoto K, Takizawa N, Matsukawa T (1999) Fast and slow recovery phases of goldfish behavior after transection of the optic nerve revealed by a computer image processing system. Neuroscience 93:907-914.

Komminoth P (1992) Digoxigenin as an alternative probe labeling for in situ hybridization. Diagn Mol Pathol 1:142-150.

Landreth GE, Agranoff BW (1976) Explant culture of adult goldfish retina: effect of prior optic nerve crush. Brain Res 118:299-303.

Li X, Sumi T, Matsukawa T, Nakanishi Y, Ohba Y (1998) Thyroid hormone, all-trans retinoic acid, and 9-cis retinoic acid functioned as negative modulators of the effect of glucocorticoid on induction of alpha 1-acid glycoprotein mRNA in RLN-10 cells. Biochem Mol Biol Int 45:1-10.

Liu ZW, Matsukawa T, Arai K, Devadas M, Nakashima H, Tanaka M, Mawatari K, Kato S (2002) Na,K-ATPase $\alpha 3$ subunit in the goldfish retina during optic nerve regeneration. J Neurochem 80:763-770.

Lowry OH, Rosebrough NJ, Farr AL, Randall RJ (1951) Protein measurement with the Folin phenol reagent. J Biol Chem 193:265-275.

Matsukawa T, Kitagawa M, Katayama K, Nagai Y, Hayashi T, Yasuda H, Ohba Y (1996) The existence of thyroid hormone responsive element, TRE, was confirmed in the first intron of alpha-acid glycoprotein gene. J Biochem 119:934-939.

McCaffery P, Leem MO, Wagner MA, Sladek NE, Drager UC (1992) Asym- metrical retinoic acid synthesis in the dorsoventral axis of the retina. Development 115:371-382.

Mey J, McCaffery P, Drager UC (1997) Retinoic acid synthesis in the developing chick retina. J Neurosci 17:7441-7449.

Noy N (2000) Retinoid-binding proteins: mediators of retinoid action. Biochem J 348:481-495.

Owusu-Yaw V, Kyle AL, Stell WK (1992) Effects of lesions of the optic nerve, optic tectum and nervus terminalis on rod precursor proliferation in the goldfish retina. Brain Res 576:220-230.

Schremser JL, Williams TP (1992) Photoreceptor plasticity in the albino rat retina following unilateral optic nerve section. Exp Eye Res 55:393-399.

Schubert D, LaCorbiere M (1985) Isolation of an adhesion-mediating protein from chick neural retina adherons. J Cell Biol 101:1071-1077.

Schubert D, LaCorbiere M, Esch F (1986) A chick neural retina adhesion and survival molecule is a retinol-binding protein. J Cell Biol 102:2295-2301.

Springer AD, Agranoff BW (1977) Effect of temperature on rate of goldfish optic nerve regeneration: a radioautographic and behavioral study. Brain Res 128:405-415.

Stell WK, Walker SE, Chohan KS, Ball AK (1984) The goldfish nervus terminalis: a luteinizing hormone-releasing hormone and molluscan cardioexcitatory peptide immunoreactive olfactoretinal pathway. Proc Natl Acad Sci USA 81:940-944.

Stull DL, Wikler KC (2000) Retinoid-dependent gene expression regulates early morphological events in the development of the murine retina. J Comp Neurol 417:289-298.

Zhelyaznik N, Schrage K, McCaffery P, Mey J (2003) Activation of retinoic acid signalling after sciatic nerve injury: up-regulation of cellular retinoid binding proteins. Eur J Neurosci 18:1033-1040. 